This manuscript was published in Animal Production Science.

Nogueira, D.M., Gardiner, C.P., Gummow, B., Cavalieri, J., Fitzpatrick, L.A., Parker, A.J., 2016a. A survey of the meat goat industry in Queensland and New South Wales. 1. General property information, goat and pasture management. Animal Production Science 56, 1520-1532.

\title{
A Survey of the Meat Goat Industry in Queensland and New South Wales. 1. General property information, goat and pasture management
}

D.M. Nogueira ${ }^{A, B^{*}}$, C.P. Gardiner ${ }^{B}$, B. Gummow ${ }^{B, C}$, J. Cavalieri $^{B}$, L.A. Fitzpatrick $^{B}$ and A.J. Parker ${ }^{B}$

${ }^{\text {A }}$ Embrapa Semiárido, BR 428, Km 142. Caixa Postal 23. CEP 56300-972, Petrolina, PE, Brazil.

${ }^{\text {B }}$ School of Veterinary and Biomedical Sciences, James Cook University, Townsville, QLD 4811, Australia.

${ }^{\mathrm{C}}$ Faculty of Veterinary Science, University of Pretoria, Pretoria, South Africa.

*Corresponding author. Email: daniel.nogueira@embrapa.br,

daniel.maianogueira@my.jcu.edu.au

Abstract. This study aimed to survey farmers' knowledge and practices on the management of pastures, stocking rates and markets of meat goat producing enterprises within New South Wales and Queensland, Australia. An interview based questionnaire was conducted on properties that derived a significant proportion of their income from goats. The survey covered 31 landholders with a total land area of 567,177 ha and a reported total of 160,010 goats. A total of 55\% (17/31) of producers were involved in both 'opportunistic harvesting' and commercial goat operations, and 45\% (14/31) were specialized seedstock producers. Goats were the most important livestock enterprise on $55 \%(17 / 31)$ of surveyed properties. Stocking rate varied considerably (0.3 to 9.3 goats/ha) within and across surveyed properties and was found to be negatively associated with property size and positively associated with rainfall. Overall, 81\% (25/31) of producers reported that the purpose of running goats on their properties was to target international markets. Producers also cited the importance of targeting markets as a way to increase profitability. Fifty-three percent of producers were located over $600 \mathrm{~km}$ from a processing plant and the high cost of freight can limit the continuity of goats supplied to abattoirs. Fencing was an important issue for goat farmers, with many producers acknowledging this could potentially add to capital costs associated with better goat management and production. Producers in the pastoral regions appear to have a low 
investment in pasture development and opportunistic goat harvesting appears to be an important source of income.

Additional keywords: feral goats, market, rangeland, seedstock producer.

\section{Introduction}

Over the past 20 years the Australian meat goat industry has experienced continuous growth, largely supported by the sale of goats derived from rangeland production systems (Dubeuf et al. 2004; McRae and Thomas 2014). In Australia there are approximately 4.5 million goats (FAO 2013), comprising 4.1 million rangeland goats and 400,000 domestic farmed goats, indicating that rangeland goats represent more than 90\% of the goat population in Australia. Australia is the largest exporter of goat meat worldwide, slaughtering more than 2.0 million goats, exporting 75,100 live goats and producing 31,700 tonnes of meat in 2013-14 (McRae and Thomas 2014). However, little data are available regarding goat production systems, goat enterprises and productivity of Australian commercial goat operations and their capacity to meet export requirements (Brice et al. 2012). Rangeland goats in Australia are descended from the first European settlements and subsequent introductions. These goats were commonly kept by householders as a source of milk and were used as draught animals, some of which established permanent populations within sparsely populated areas of Australia (Restall et al. 1982). Rangeland goats are now declared as a pest in every state and territory in Australia with the exception of the state of New South Wales (Restall et al. 1982; Parkes et al. 1996). Inadequate management of rangeland goats can cause environmental degradation (Bayne et al. 2004; Brice et al. 2012; Khairo et al. 2013). Thus most State governments in Australia view rangeland goats as detrimental to the environment and favour eradication rather than seeing the goats as a potential source of income (Khairo et al. 2013). Others view goats as an aid for the control of woody weeds and pasture manipulation (Silanikove 2000; McGregor 2010a), a potential source of supplementary income for pastoral industries, an emerging commodity for organically produced products and as a strategy for complementary pasture management associated with cattle production (Boyazoglu et al. 2005).

Since over $90 \%$ of the goat herd in Australia is derived from rangeland goats, improvements in the productivity and management of rangeland enterprises could have an important effect on the profitability of these enterprises (MLA 2013). A survey was 
therefore designed to build a better understanding of the goat industry in New South Wales and Queensland. The aim of this study was to survey farmers' knowledge and practices on the management of pastures, stocking rates and markets utilised by meat goat producing enterprises within New South Wales and Queensland. A companion paper to this publication will discuss herd management, reproductive performance and animal health (Nogueira et al., 2014).

\section{Material and Methods}

\section{Survey design and structure}

An interview based questionnaire was developed to survey meat goat properties located in Queensland (QLD) and New South Wales (NSW) during 2013. The questionnaire covered the period from 2012 to 2013 and consisted of 106 questions and was designed to take an average of 2.5 hours to be completed. The majority of the questions were in a multiple tick-a-box format and were based on a previous beef industry survey reported by Bortolussi et al. (2005a).

The survey was conducted face to face where one or two interviewers visited the meat goat producers and completed the questionnaire with them. Goat producers were the owners of properties that derived income from goats. Face to face interviews were used to ensure a consistent approach and interpretation of the questions and answers, as well to ensure a high return rate. The template questionnaire was approved by the Human Ethics Committee of James Cook University (approval number: ID H4415).

Information was collected on property location, property area, herd size, rainfall, soils, vegetation, pasture management practices, stocking rate, infrastructure development, use of fire and wood weeds, types of production activities and goat meat markets, market aspiration and whether or not market specifications are met. Further information was also collected on herd management, reproductive performance and animal health, and is presented in Nogueira et al., 2014.

\section{Survey validation}

To manage the quality of data collected, most survey questions were crossreferenced where responses to a particular question could be cross-checked and/or validated by the response to a previous or subsequent question (Bortolussi et al. 2005b). In addition, there were some follow-up calls or emails after the survey for clarification of 
responses. The questionnaire was tested with four producers prior to the survey and a revised questionnaire was then used with the wider survey group. On most properties, an inspection of pasture and herd management was conducted with the authorization and presence of the owner. Inspecting the pasture and the herd was to confirm the information obtained in the questionnaire.

\section{Survey population}

The Survey was carried out in Queensland and New South Wales, and involved owners of 31 properties that derived income from goats. A goat producer was defined as an entity that obtained a significant proportion of income from meat goats. Meat goat producers were recruited non-randomly through a direct approach. The sample frame comprised farmers who were members of Meat and Livestock Australia (MLA) and the Boer Goat Breeders Association. The producers were screened to include only commercial private goat producers and corporate companies, and those willing to participate in the survey were then included. The first contact with producers was done either by telephone or email, when the purpose of the survey was explained. Seventy-four percent (31/42) of goat producers approached were willing to participate in the survey. They formed six clusters representing the major goat producing areas in Queensland and New South Wales (Fig. 1). The properties were clustered according to proximity and labelled as regions 1 to 6 (Table 1). 


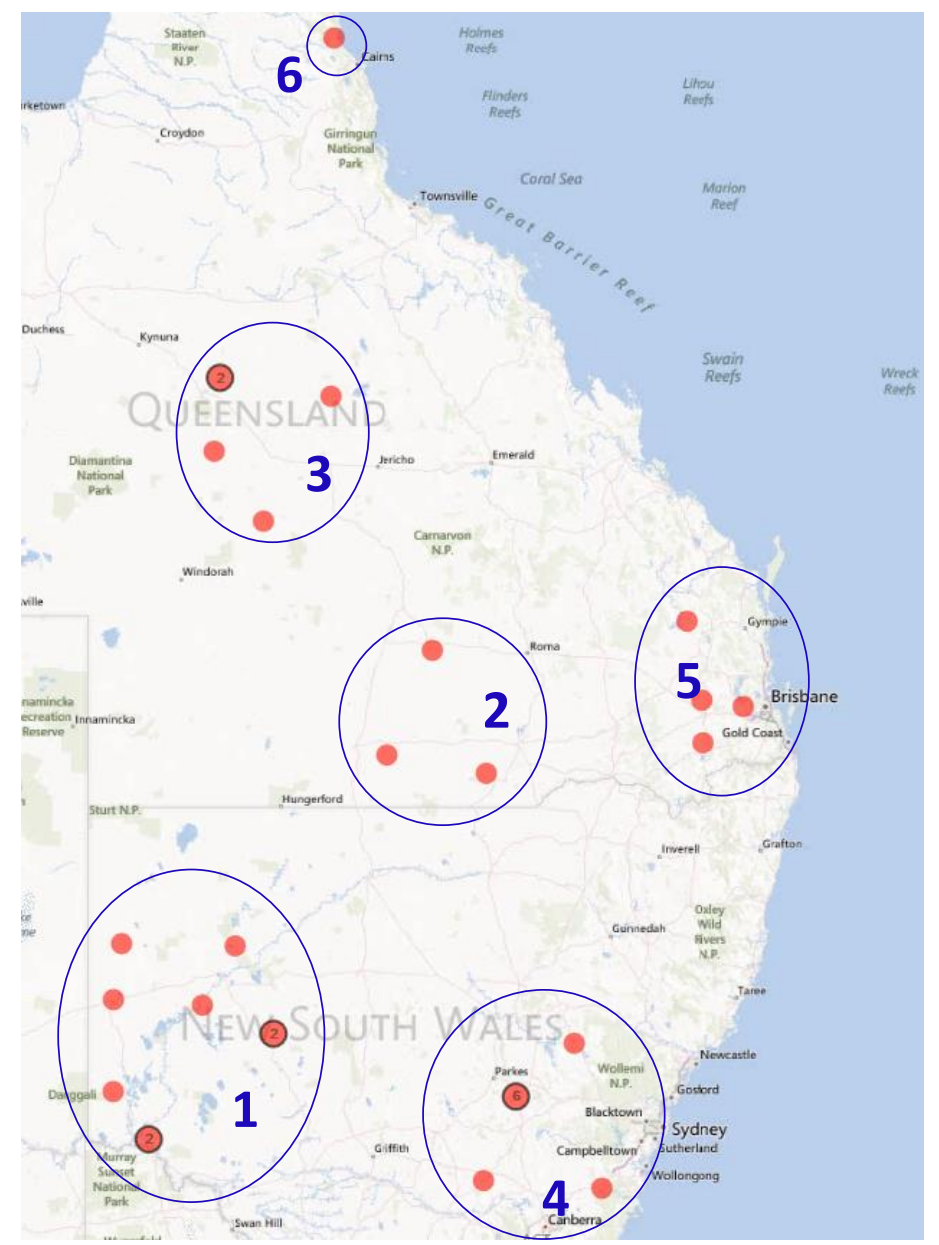

Fig. 1. Location of properties included in the survey, which were clustered in three pastoral regions (1,2 and 3) and three high rainfall regions (4, 5 and 6) of Queensland and New South Wales.

Table 1. Brief description of the surveyed regions in Queensland and New South Wales adapted from the Interim Biogeographic Regionalisation for Australia.

\begin{tabular}{|c|c|c|c|c|c|c|}
\hline Region & $\begin{array}{c}\text { Bioregion } \\
\text { (predominant) }\end{array}$ & $\begin{array}{c}\text { Towns } \\
\text { closest to } \\
\text { survey sites }\end{array}$ & $\begin{array}{c}\text { Annual } \\
\text { Rainfall } \\
\text { (range) }\end{array}$ & $\begin{array}{l}\text { Temperature } \\
\text { (average max } \\
\text { and min) }\end{array}$ & $\begin{array}{l}\text { Altitude } \\
\text { (sea } \\
\text { level) }\end{array}$ & $\begin{array}{l}\text { Climate } \\
\text { (Köppen) }\end{array}$ \\
\hline $\begin{array}{c}1 . \\
\text { Western } \\
\text { NSW }\end{array}$ & $\begin{array}{c}\text { Broken Hill } \\
\text { Complex }\end{array}$ & $\begin{array}{c}\text { Broken Hill, } \\
\text { Mildura, } \\
\text { Wilcannia }\end{array}$ & $\begin{array}{c}130 \mathrm{~mm} \\
\text { to } 250 \\
\mathrm{~mm} .\end{array}$ & $\begin{array}{l}\text { Summer: } \\
34^{\circ} \mathrm{C} \\
\text { Winter: } 5^{\circ} \mathrm{C}\end{array}$ & $\begin{array}{l}94 \mathrm{~m} \text { to } \\
315 \mathrm{~m}\end{array}$ & $\begin{array}{l}\text { Hot desert } \\
\text { climate. }\end{array}$ \\
\hline $\begin{array}{c}2 . \\
\text { South- } \\
\text { western } \\
\text { QLD }\end{array}$ & Mulga Lands & $\begin{array}{c}\text { Dirranbandi, } \\
\text { Morven, } \\
\text { Charleville }\end{array}$ & $\begin{array}{l}500 \\
\mathrm{~mm} .\end{array}$ & $\begin{array}{l}\text { Summer: } \\
35^{\circ} \mathrm{C} \\
\text { Winter: } 18^{\circ} \mathrm{C}\end{array}$ & $\begin{array}{l}170 \mathrm{~m} \text { to } \\
290 \mathrm{~m}\end{array}$ & $\begin{array}{l}\text { Hot, dry, } \\
\text { semi-arid } \\
\text { climate }\end{array}$ \\
\hline $\begin{array}{c}3 . \\
\text { Central- } \\
\text { western } \\
\text { QLD }\end{array}$ & $\begin{array}{c}\text { Mitchell } \\
\text { Grass Downs }\end{array}$ & $\begin{array}{l}\text { Corfield, } \\
\text { Longreach, } \\
\text { Isisford }\end{array}$ & $\begin{array}{c}250 \mathrm{~mm} \\
\text { to } 500 \\
\mathrm{~mm}\end{array}$ & $\begin{array}{l}\text { Summer: } \\
38^{\circ} \mathrm{C} \text { Winter: } \\
12^{\circ} \mathrm{C} \text {. }\end{array}$ & $\begin{array}{l}191 \mathrm{~m} \text { to } \\
203 \mathrm{~m}\end{array}$ & $\begin{array}{c}\text { Dry } \\
\text { monsoonal to } \\
\text { semi-arid } \\
\text { climate }\end{array}$ \\
\hline
\end{tabular}




\begin{tabular}{|c|c|c|c|c|c|c|}
\hline $\begin{array}{c}4 . \\
\text { Eastern } \\
\text { NSW }\end{array}$ & $\begin{array}{l}\text { South- } \\
\text { western } \\
\text { Slopes }\end{array}$ & $\begin{array}{c}\text { Forbes, } \\
\text { Mudgee, } \\
\text { Cootamundra }\end{array}$ & $\begin{array}{c}600 \mathrm{~mm} \\
\text { to } 750 \\
\mathrm{~mm} .\end{array}$ & $\begin{array}{l}\text { Summer: } \\
28^{\circ} \mathrm{C} \\
\text { Winter: } 2{ }^{\circ} \mathrm{C}\end{array}$ & $\begin{array}{l}240 \mathrm{~m} \text { to } \\
320 \mathrm{~m}\end{array}$ & $\begin{array}{c}\text { Humid, high } \\
\text { rainfall, } \\
\text { temperate } \\
\text { climate and } \\
\text { hot summers }\end{array}$ \\
\hline $\begin{array}{l}5 . \\
\text { South- } \\
\text { eastern } \\
\text { QLD }\end{array}$ & South-eastern & $\begin{array}{l}\text { Wivenhoe } \\
\text { Pocket, } \\
\text { Toowoomba, } \\
\text { Proston }\end{array}$ & $\begin{array}{l}700 \mathrm{~mm} \\
\text { to } 944 \\
\mathrm{~mm}\end{array}$ & $\begin{array}{l}\text { Summer: } \\
23^{\circ} \mathrm{C} \text { Winter: } \\
9^{\circ} \mathrm{C}\end{array}$ & $\begin{array}{l}458 \mathrm{~m} \text { to } \\
691 \mathrm{~m}\end{array}$ & $\begin{array}{c}\text { Subtropical } \\
\text { highland with } \\
\text { warm } \\
\text { summers and } \\
\text { cool winters }\end{array}$ \\
\hline $\begin{array}{l}6 . \\
\text { Far } \\
\text { North } \\
\text { QLD }\end{array}$ & Wet Tropics & Mossman & $\begin{array}{l}2,010 \\
\mathrm{~mm}\end{array}$ & $\begin{array}{l}\text { Summer: } \\
28^{\circ} \mathrm{C} \text { Winter: } \\
20^{\circ} \mathrm{C}\end{array}$ & $4 \mathrm{~m}$ & $\begin{array}{c}\text { Tropical } \\
\text { monsoon } \\
\text { climate with } \\
\text { summer wet } \\
\text { season }\end{array}$ \\
\hline
\end{tabular}

Source: Adapted from the Interim Biogeographic Regionalisation for Australia (IBRA 2014).

\section{Definition of terms and parameters evaluated:}

'Pastoral regions' refers to properties located in the western NSW and western QLD (Regions 1, 2 and 3). They are characterised as an arid environment (130 $\mathrm{mm}$ to $500 \mathrm{~mm}$ rainfall) and span various climatic zones from summer dominant rainfall in the north to winter dominant rainfall in the south, with wide variation in soil types and vegetation species. Livestock production from pasture (extensive grazing) is the main source of farm income. 'High rainfall regions' refers to properties located in the eastern NSW, eastern QLD and far north QLD (Regions 4, 5, and 6), with an annual rainfall of more than $600 \mathrm{~mm}$. These properties are smaller and livestock are raised under an intensive grazing management system. 'Domestic market' was considered as the commercialization of goat meat to restaurants, store operations, and goats sold to depots from dealer operations or goats sold to another property. 'International market' was considered as live animals or goat meat sold for use outside the country, including live export and carcass export. 'Live export' refers to live goats that were sold either unfinished or finished for use in markets overseas. 'Seedstock' refers to goat stock sold for use in herd breeding programs from registered studs. 'Store' refers to goats sold in an unfinished condition to be grown and/or fattened or used for breeding elsewhere within Australia.

The 'stocking rates (goats/ha)' was reported firstly by respondents stating their perceived stocking rate for the area on their property dedicated to goat production. Secondly, the stocking rate was calculated by taking the total number of goats run on the 
property and dividing by the area (ha) on the property dedicated to goat production. The unit 'goats/ha' is equivalent to one non-breeding doe per ha which is equal to 1.2 DSE (McGregor 2010b). 'Scrub soils' were reported by producers to describe an association with many other soils, as shallow dense loam soils, sand spreads or dark cracking clays often dominated by shrubs, including grasses and herbs. 'Clay Soils' were classified as vertosols which are defined by shrink-swell soils that exhibit strong cracking when dry and at depth have slicken sides and/or lenticular structural aggregates. 'Rocky/skeletal soils' were shallow porous loam soils, associated with stones, gravels or rock walls, with neutral and alkaline yellow mottled soils. 'Paddock spelling' is a strategy of removing the stock from pasture to promote recovery and regeneration of vegetation.

\section{Data analysis}

Descriptive statistical procedures were used to compare surveyed regions. The data analyses are presented as means and standard deviations, frequencies and crosstabulation tables. Stocking rate was calculated by taking the total number of goats run on a given property and dividing by the area (ha) on the property dedicated to goat production. Overall percentages were calculated by the number of properties in both pastoral and high rainfall regions showing the characteristics divided by total number of properties $(\mathrm{n}=31)$ and multiplied by 100 . Correlation among number of goats in a herd, stocking rate, rainfall and property size were obtained by the Pearson and Spearman tests. Data expressed as percentages were compared using the Chi-square test. Data were analyzed using Epi Info software (Epi Info ${ }^{\mathrm{TM}}$ 7.1.1.14, USA, 2013). Differences were considered significant when $\mathrm{P}<0.05$.

\section{Results}

\section{Scope of the survey and goat herd}

The survey covered 31 landholders with a total land area of 567,177 ha and a reported total of 160,010 goats (Table 2). The properties in NSW constituted 58\% (18/31) and those in QLD constituted 42\% (13/31) of the surveyed properties. The properties located in the pastoral region (western NSW, south-western QLD and central-western QLD) covered larger areas and the greatest number of goats per property, and represented $55 \%(17 / 31)$ of producers. These pastoral area producers were predominately involved in 'opportunistic harvesting' and commercial goat operations. In contrast, the properties 
located in the high rainfall regions (eastern NSW, south-eastern QLD and far north QLD) covered smaller areas with fewer numbers of goats, and represented 45\% (14/31) of producers specialized in seedstock breeding. In addition, the properties located in the pastoral regions covered $99 \%$ of the land area of the surveyed properties and the rangeland goats from these properties comprised $97 \%$ of the goat herd covered in this survey. Hence, the domestic farmed goats of seedstock producers from high rainfall regions only made up $3 \%$ of the goat herd covered in this survey (Table 2). 
Table 2. The number of properties, total land area and total goat herd size reported from surveyed regions of New South Wales and Queensland from 2012 to 2013

\begin{tabular}{|c|c|c|c|c|c|c|c|c|c|}
\hline \multirow[b]{2}{*}{ Characteristics } & \multicolumn{3}{|c|}{ Pastoral regions } & \multirow[b]{2}{*}{ Subtotal } & \multicolumn{3}{|c|}{ High rainfall regions } & \multirow[b]{2}{*}{ Subtotal } & \multirow[b]{2}{*}{ Total } \\
\hline & $\begin{array}{l}\text { West } \\
\text { NSW }\end{array}$ & $\begin{array}{c}\text { S.West } \\
\text { QLD }\end{array}$ & $\begin{array}{l}\text { C.West } \\
\text { QLD }\end{array}$ & & $\begin{array}{c}\text { East } \\
\text { NSW }\end{array}$ & $\begin{array}{l}\text { S.East } \\
\text { QLD }\end{array}$ & $\begin{array}{l}\text { North } \\
\text { QLD }\end{array}$ & & \\
\hline Number of properties & 9 & 3 & 5 & 17 & 9 & 4 & 1 & 14 & 31 \\
\hline \multicolumn{10}{|c|}{ Property area (ha) } \\
\hline Total area covered (ha) & 391,917 & 96,146 & 74,601 & 562,664 & 3,869 & 482 & 162 & 4,513 & 567,177 \\
\hline Total area $(\%)$ & 69.1 & 17.0 & 13.2 & $99 \%$ & 0.7 & 0.1 & 0.03 & $1 \%$ & 100 \\
\hline Mean property size (ha) & 43,546 & 32,049 & 14,920 & 33,098 & 430 & 121 & 162 & 322 & 18,296 \\
\hline $\begin{array}{l}\text { Mean area utilized for } \\
\text { goats }(\%)\end{array}$ & 72 & 45 & 28 & 54 & 68 & 70 & 15 & 64 & the \\
\hline \multicolumn{10}{|c|}{$\operatorname{Rainfall}(\mathrm{mm})^{*}$} \\
\hline$<250$ & 5 & 0 & 0 & 5 & 0 & 0 & 0 & & $5(16)$ \\
\hline 250 to 500 & 4 & 3 & 4 & 11 & 0 & 1 & 0 & 1 & $12(39)$ \\
\hline 501 to 750 & 0 & 0 & 1 & 1 & 9 & 3 & 0 & 12 & $13(42)$ \\
\hline$>751$ & 0 & 0 & 0 & 0 & 0 & 0 & 1 & 1 & $1(3)$ \\
\hline \multicolumn{10}{|c|}{ Stocking rate (goat/ha, mean $\pm S D)$} \\
\hline Reported (goats/ha) & $0.3 \pm 0.2$ & $0.7 \pm 0.5$ & $0.6 \pm 0.2$ & $0.4 \pm 0.3$ & $5.0 \pm 3.2$ & $3.2 \pm 2.0$ & 5.1 & $4.5 \pm 2.8$ & . \\
\hline Calculated (goats/ha) & $0.6 \pm 0.4$ & $0.5 \pm 0.2$ & $1.0 \pm 0.7$ & $0.7 \pm 0.5$ & $4.1 \pm 2.4$ & $2.6 \pm 1.7$ & 6.2 & $4.3 \pm 2.3$ & . \\
\hline \multicolumn{10}{|c|}{ Goat herd (head) } \\
\hline Total goat herd in 2013 & 110,100 & 30,500 & 14,300 & 154,900 & 4,320 & 640 & 150 & 5,110 & 160,010 \\
\hline Goat herd in $2013(\%)$ & 68.8 & 19.1 & 8.9 & $97 \%$ & 2.7 & 0.4 & 0.1 & $3 \%$ & 100 \\
\hline Total goat sold in 2012 & 86,059 & 14,425 & 18,460 & 118,944 & 1,463 & 386 & 50 & 1,899 & 120,843 \\
\hline
\end{tabular}




\section{General property information}

Overall, 32\% (10/31) of surveyed properties were run in conjunction with another property and $100 \%$ of surveyed properties were managed by family members. Daily rainfall records were recorded by $77 \%$ (24/31) of the surveyed properties and 50\% (12/24) of these properties showed a rainfall of less than $500 \mathrm{~mm} / \mathrm{year}$. The only extreme was a property located in far north QLD, which recorded the highest rainfall (2,500 mm/year). The properties located in western NSW had greater areas allocated to goat production and reported the lowest annual average rainfalls. Figure 2 a shows that the greatest numbers of goats were found on the largest properties $\left(y=0.3 x+159.5 ; r^{2}=0.7 ; P<0.05\right)$.

\section{Stocking rate}

A majority of producers surveyed stated that they determined stocking rate by 'eye and experience'. Figure $2 \mathrm{~b}$ shows that the stocking rates increased on the smaller size properties, presenting a negative association $\left(\mathrm{y}=-0.5 \ln (\mathrm{x})+6.3 ; \mathrm{r}^{2}=0.6 ; \mathrm{P}<0.05\right)$. The mean stocking rates reported in the pastoral regions varied from 0.3 to 1.2 goats/ha and the stocking rates in the high rainfall regions varied from 3.2 to 9.3 goats/ha (Table 2).

A total of $42 \%$ (13/31) of the surveyed properties occupied land areas greater than 15,000 ha (Fig. 2). In general, the producer's reported stocking rates were similar and followed the same trend as the calculated stocking rates $\left(\mathrm{r}^{2}=0.57 ; \mathrm{P}<0.05\right)$; however, producers in western NSW and central-western QLD reported lower average stocking rate (Table 2, Fig.2b).

A negative association was found between rainfall and property size, with lesser rainfall regions associated with greater property sizes (Fig. 2c). Producers were asked if the number of goats carried would vary according to the seasonal conditions. The results showed that during a 'good season', the number of goats would increase up to $147 \%$ (Table 3). Only the properties in the pastoral regions reported that the number of goats varied significantly with times of the year due to changes in seasonal conditions. During a 'poor season' the number of goats would be reduced to $27 \%$ of the 2012 herd population (Table 3). The percentage of animals in the high rainfall regions varied little between the seasonal conditions. 

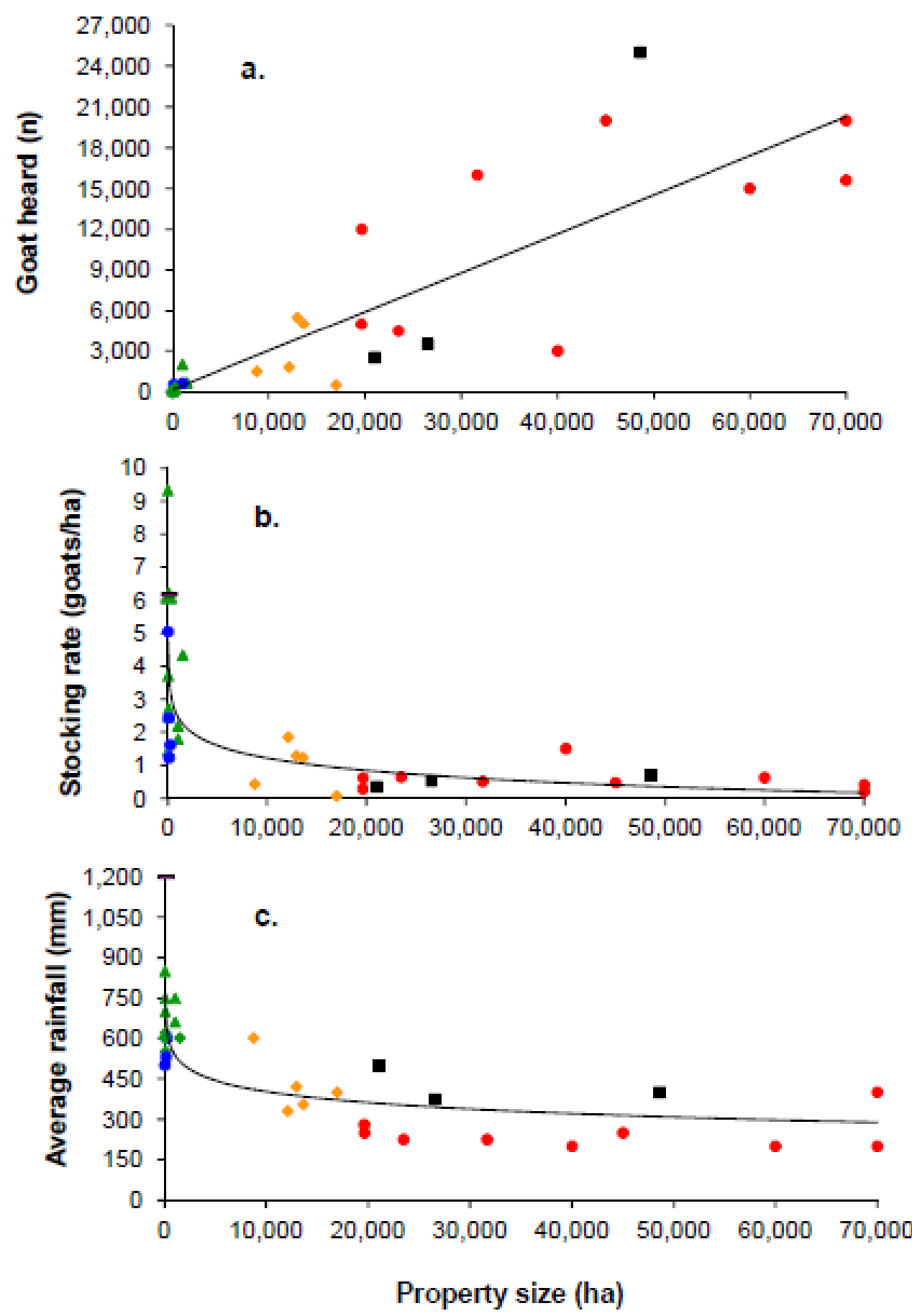

Fig. 2. Association between the property size and goat herd (a) $\left(y=0.3 x+159.5 ; r^{2}=\right.$ $0.7 ; \mathrm{P}<0.05)$, property size and stocking rate $(\mathbf{b})\left(\mathrm{y}=-0.5 \ln (\mathrm{x})+6.3, \mathrm{r}^{2}=0.6 ; \mathrm{P}<0.05\right)$ and property size and rainfall $(\mathbf{c})\left(\mathrm{y}=-57.3 \ln (\mathrm{x})+931.8, \mathrm{r}^{2}=0.6 ; \mathrm{P}<0.05\right)$ for the

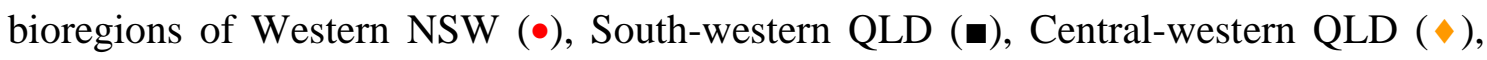
Eastern NSW ( $\bullet$ ), South-eastern QLD (•) and North QLD (-). 
Table 3. Relative carrying capacity of goats according to producer's assessment of pastoral conditions (poor, average and good) compared to the year of 2012*

\begin{tabular}{lllllllll}
\hline & \multicolumn{3}{c}{ Pastoral regions } & & \multicolumn{3}{c}{ High rainfall regions } & \\
\cline { 2 - 5 } \cline { 7 - 8 } Pastoral & West & S.West & C.West & Subtotal & East & S.East & North & Subtotal \\
condition & NSW & QLD & QLD & mean \pm SD & NSW & QLD & QLD & mean \pm SD \\
\hline Poor $(\%)$ & 50 & 34 & 60 & $51 \pm 24$ & 77 & 91 & 80 & $82 \pm 18$ \\
Average $(\%)$ & 82 & 72 & 78 & $79 \pm 13$ & 99 & 96 & 80 & $97 \pm 7$ \\
Good (\%) & 116 & 115 & 122 & $117 \pm 30$ & 105 & 104 & 100 & $105 \pm 14$ \\
\hline
\end{tabular}

$* 100 \%$ was the percentage of goats in 2012.

\section{Goat as the main livestock enterprise and the goat meat markets}

Most of the properties were involved in more than one livestock enterprise, usually goats, sheep and cattle. The producers indicated the main livestock enterprise in order of importance to their property. Goats were the most important livestock enterprise on 55\% (17/31) of surveyed properties, 32\% (10/31) of producers reported that sheep production was the main enterprise and only $13 \%$ (4/31) reported cattle production as the main enterprise. None of the properties located in central-western QLD reported that goats were the main livestock enterprise. However, 67\% (6/9) of the properties located in western NSW and 78\% (7/9) in eastern NSW reported that goats were the most important livestock enterprise on the surveyed properties.

Overall, when the producers were asked what was the purpose of running goats on their property (Table 4), 81\% (25/31) reported targeting international markets, 58\% (18/31) reported targeting the domestic market and 29\% (9/31) reported that the goat herd was used for weed control. Overall, there was no difference $(\mathrm{P}>0.05)$ between numbers of producers that reported targeting the international and domestic market. However, the percentage of producers that targeted meat markets as a primary consideration for running goats was significantly greater $(\mathrm{P}<0.05)$ than producers who used goats for weed control. The producers that considered goats as the main livestock enterprise reported the following hierarchical preference for markets: international market (100\%), domestic market $(65 \%)$ and weed control $(18 \%$; $\mathrm{P}<0.05$; Table 4$)$. 
Table 4. Cross tabulation between main livestock enterprise and the reason for running goats on properties surveyed in NSW and QLD, Australia

\begin{tabular}{lllll}
\hline \multirow{2}{*}{$\begin{array}{l}\text { Main } \\
\text { Livestock }\end{array}$} & $\%(\mathrm{n})$ & \multicolumn{3}{c}{ Reasons for running goats \%, (n) } \\
\cline { 3 - 5 } & & $\begin{array}{l}\text { International } \\
\text { market }\end{array}$ & $\begin{array}{l}\text { Domestic } \\
\text { market }\end{array}$ & Weed control \\
\hline Goats & $55(17 / 31)$ & $100(17 / 17)^{\mathbf{a}}$ & $65(11 / 17)^{\mathbf{b}}$ & $18(3 / 17)^{\mathbf{c}}$ \\
Sheep & $32(10 / 31)$ & $50(5 / 10)$ & $50(5 / 10)$ & $50(5 / 10)$ \\
Cattle & $13(4 / 31)$ & $75(3 / 4)$ & $50(2 / 4)$ & $25(1 / 4)$ \\
$\begin{array}{l}\text { Overall \%, } \\
\text { (n) }\end{array}$ & 100 & $81(25 / 31)^{\mathbf{a}}$ & $58(18 / 31)^{\mathbf{a}}$ & $29(9 / 31)^{\mathbf{c}}$ \\
\hline
\end{tabular}

*Number of properties. Values with different letters in the same row are significantly different with a Chi-square test $(\mathrm{P}<0.05)$.

All producers reported more than one goat enterprise activity on their property (Table 5). The majority of producers in NSW and QLD $(68 \% ; 21 / 31)$ reported breeding stores and replacements as the most common activity on goat properties. Opportunistic harvesting was the first most common activity reported by $88 \%(15 / 17)$ of producers in the pastoral regions (Table 5). All of the surveyed properties located in western NSW carried out opportunistic harvesting of goats and $100 \%$ of properties in central-western QLD carried out breeding-finishing of goats on native pasture. In addition, all the properties located in the high rainfall regions were Boer goat seedstock producers (Table 5).

Overall, the first three market sectors reported by producers in order of importance were: domestic market with $81 \%$ (25/31), live export with $68 \%$ (21/31), carcass export with 61\% (19/31) and 13\% (4/31) for restaurants (Table 6). The carcass export market was mentioned as the dominant market sector by $100 \%$ of producers located in western NSW, south-western QLD and central-western QLD (Table 6). A total of 81\% (25/31) of the producers reported they had sold goats to the international market. When producers were asked to identify international markets that they supplied, Asia was identified by $52 \%(16 / 31)$ of producers, $29 \%$ (9/31) identified sales to the USA and 13\% (4/31) to the Middle East. Exports of carcasses were reportedly sold to the USA and the live goat export trade was directed towards Asia and the Middle East. Live goat exports to Malaysia was the most cited country by the producers located in central-western QLD. The range reported export carcass weight varied from $15.5 \mathrm{~kg}$ to $22.5 \mathrm{~kg}$ (Table 6).

One of the biggest concerns reported by the majority of producers located in the pastoral regions $(53 \%$; 9/17) was the distance from their property to the abattoir. Distances greater than $700 \mathrm{~km}$ were reported by producers from western NSW (Table 6). 
Overall, 84\% (26/31) of producers reported a willingness to change the management of their enterprises over the next 5 years to increase profitability and 16\% (5/31) of respondents said that no changes would be made (Table 7). The producers willing to increase their profitability reported adopting the following strategies: 48\% (15/31) reported focusing on target markets, 45\% (14/31) improving pasture management, 35\% $(11 / 31)$ introducing better quality bucks and the minority were associated with herd management issues, such as reducing the death rate, increasing weight at turn-off and increasing marking percentage (Table 7$)$. A total of $71 \%(22 / 31)$ of producers of all regions reported they needed additional help in the promotion and advertisement of goat meat for consumption in Australian and international markets. 
Table 5. The number of properties in New South Wales and Queensland conducting various goat enterprises

\begin{tabular}{|c|c|c|c|c|c|c|c|c|c|}
\hline & \multicolumn{3}{|c|}{ Pastoral regions } & \multirow[b]{2}{*}{$\begin{array}{c}\text { Subtotal } \\
n\end{array}$} & \multicolumn{3}{|c|}{ High rainfall regions } & \multirow[b]{2}{*}{$\begin{array}{c}\text { Subtotal } \\
\mathrm{n}\end{array}$} & \multirow[b]{2}{*}{$\begin{array}{c}\text { Overall } \\
\mathrm{n}(\%)\end{array}$} \\
\hline & $\begin{array}{l}\text { West } \\
\text { NSW }\end{array}$ & $\begin{array}{l}\text { S.West } \\
\text { QLD }\end{array}$ & $\begin{array}{c}\text { C.West } \\
\text { QLD }\end{array}$ & & $\begin{array}{l}\text { East } \\
\text { NSW }\end{array}$ & $\begin{array}{l}\text { S.East } \\
\text { QLD }\end{array}$ & $\begin{array}{l}\text { North } \\
\text { QLD }\end{array}$ & & \\
\hline Number of enterprises & 9 & 3 & 5 & 17 & 9 & 4 & 1 & 14 & $31(100)$ \\
\hline \multicolumn{10}{|c|}{ Number of properties by enterprise } \\
\hline 1 enterprises & 2 & 1 & 1 & 4 & 0 & 2 & 1 & 3 & $7(23)$ \\
\hline 2 enterprises & 6 & 1 & 1 & 8 & 3 & 1 & 0 & 4 & $12(39)$ \\
\hline 3 or 4 enterprises & 1 & 1 & 3 & 5 & 6 & 1 & 0 & 7 & $12(39)$ \\
\hline \multicolumn{10}{|c|}{ Enterprises carried out } \\
\hline Breeding stores/replacements & 4 & 2 & 2 & 8 & 9 & 3 & 1 & 13 & $21(68)$ \\
\hline Opportunistic harvesting & 9 & 2 & 4 & 15 & 0 & 0 & 0 & 0 & $15(48)$ \\
\hline Seedstock producer & 0 & 0 & 0 & 0 & 9 & 4 & 1 & 14 & $14(45)$ \\
\hline Breeding-finishing on pasture & 3 & 1 & 5 & 9 & 4 & 1 & 0 & 5 & $14(45)$ \\
\hline Breeding-finishing on crop & 0 & 1 & 0 & 1 & 4 & 1 & 0 & 5 & $6(19)$ \\
\hline Buying-finishing on pasture & 2 & 1 & 2 & 5 & 0 & 0 & 0 & 0 & $5(16)$ \\
\hline
\end{tabular}


Table 6. Number of properties targeting goat meat market sectors, typical export market weight and the shortest distance from surveyed properties in to the closest abattoir

\begin{tabular}{|c|c|c|c|c|c|c|c|c|c|}
\hline & \multicolumn{3}{|c|}{ Pastoral regions } & \multirow[b]{2}{*}{$\begin{array}{c}\text { Subtotal } \\
n\end{array}$} & \multicolumn{3}{|c|}{ High rainfall regions } & \multirow[b]{2}{*}{$\begin{array}{c}\text { Subtotal } \\
n\end{array}$} & \multirow[b]{2}{*}{$\begin{array}{c}\text { Overall } \\
\mathrm{n}(\%)\end{array}$} \\
\hline & $\begin{array}{l}\text { West } \\
\text { NSW }\end{array}$ & $\begin{array}{c}\text { S.West } \\
\text { QLD }\end{array}$ & $\begin{array}{l}\text { C.West } \\
\text { QLD }\end{array}$ & & $\begin{array}{c}\text { East } \\
\text { NSW }\end{array}$ & $\begin{array}{l}\text { S.East } \\
\text { QLD }\end{array}$ & $\begin{array}{l}\text { North } \\
\text { QLD }\end{array}$ & & \\
\hline$\overline{\text { Number of sectors selected }}$ & 9 & 3 & 5 & 17 & 9 & 4 & 1 & 14 & $31(100)$ \\
\hline \multicolumn{10}{|c|}{ Number of properties by sector } \\
\hline 1 sector & 5 & 0 & 1 & 6 & 0 & 2 & 0 & 2 & $8(26)$ \\
\hline 2 sectors & 1 & 1 & 1 & 3 & 5 & 2 & 1 & 8 & $11(35)$ \\
\hline 3 sectors & 1 & 2 & 3 & 6 & 3 & 0 & 0 & 3 & $9(29)$ \\
\hline 4 sectors & 2 & 0 & 0 & 2 & 1 & 0 & 0 & 1 & $3(10)$ \\
\hline \multicolumn{10}{|c|}{ Markets sectors for goat meat } \\
\hline Domestic market & 5 & 3 & 4 & 12 & 9 & 3 & 1 & 13 & $25(81)$ \\
\hline Live export & 3 & 2 & 3 & 8 & 9 & 3 & 1 & 13 & $21(68)$ \\
\hline Carcass export & 9 & 3 & 5 & 17 & 2 & 0 & 0 & 2 & $19(61)$ \\
\hline Restaurant & 1 & 0 & 0 & 1 & 3 & 0 & 0 & 3 & $4(13)$ \\
\hline Carcass weight $(\mathrm{kg})$ & $15.5 \pm 2.1$ & $20 \pm 0.5$ & $15.3 \pm 0.6$ & $16.2 \pm 2.1$ & $22.5 \pm 3.5$ & $*$ & $*$ & $22.5 \pm 3.5$ & $17.7 \pm 3.6$ \\
\hline Closest abattoir $(\mathrm{km})$ & $720 \pm 80$ & $425 \pm 177$ & $574 \pm 64$ & $637 \pm 134$ & $242 \pm 200$ & $75 \pm 84$ & 120 & $176 \pm 190$ & \\
\hline
\end{tabular}

* Producers from south-eastern QLD and north QLD only sold breeding animals. 
Table 7. Changes over the next 5 years to increase profitability on the properties of New South Wales and Queensland

\begin{tabular}{|c|c|c|c|c|c|c|c|c|c|}
\hline \multirow[b]{2}{*}{ Increase profitability } & \multicolumn{3}{|c|}{ Pastoral regions } & \multirow[b]{2}{*}{$\begin{array}{c}\text { Subtotal } \\
\mathrm{n}\end{array}$} & \multicolumn{3}{|c|}{ High rainfall regions } & \multirow[b]{2}{*}{$\begin{array}{c}\text { Subtotal } \\
\mathrm{n}\end{array}$} & \multirow[b]{2}{*}{$\begin{array}{c}\text { Overall } \\
\mathrm{n}\left(\%^{1}\right)\end{array}$} \\
\hline & $\begin{array}{l}\text { West } \\
\text { NSW }\end{array}$ & $\begin{array}{c}\text { S.West } \\
\text { QLD }\end{array}$ & $\begin{array}{l}\text { C.West } \\
\text { QLD }\end{array}$ & & $\begin{array}{c}\text { East } \\
\text { NSW }\end{array}$ & $\begin{array}{l}\text { S.East } \\
\text { QLD }\end{array}$ & $\begin{array}{l}\text { North } \\
\text { QLD }\end{array}$ & & \\
\hline Make no changes & 2 & 1 & 2 & 5 & 0 & 0 & 0 & 0 & $5(16)$ \\
\hline Target markets & 3 & 0 & 2 & 5 & 6 & 3 & 1 & 10 & $15(48)$ \\
\hline Better pasture management & 1 & 1 & 2 & 4 & 8 & 1 & 1 & 10 & $14(45)$ \\
\hline Better quality bucks & 0 & 0 & 1 & 1 & 5 & 4 & 1 & 10 & $11(35)$ \\
\hline Reduce turn-off age & 3 & 0 & 1 & 4 & 1 & 0 & 1 & 2 & $6(19)$ \\
\hline Increase herd size & 0 & 1 & 1 & 2 & 2 & 2 & 0 & 4 & $6(19)$ \\
\hline Reduce herd size & 1 & 0 & 1 & 2 & 1 & 2 & 0 & 3 & $5(16)$ \\
\hline Reduce death rate & 1 & 1 & 1 & 3 & 1 & 0 & 1 & 2 & $5(16)$ \\
\hline Increase turn-off weight & 1 & 1 & 0 & 2 & 2 & 0 & 1 & 3 & $5(16)$ \\
\hline Increase marking rate & 2 & 0 & 0 & 2 & 2 & 0 & 1 & 3 & $5(16)$ \\
\hline
\end{tabular}

${ }^{1}$ From the total number of properties $(n=31)$. 


\section{Land and soil}

A total of 55\% (17/31) of producers reported they had very good or good land condition, although 42\% (13/31) of producers in any region reported some land erosion (Table 8). In contrast to the reported good land condition, 61\% (19/31) of producers reported they had an average or poor pasture condition. Paddock spelling was practiced by $90 \%$ (28/31) of producers in all regions. The same majority of producers $(90 \%)$ indicated that land management issues influenced their property management decisions. Clay soil and its derivatives were the major soil type reported by $68 \%$ (21/31) of producers (Table 8). Clay soils existed in all of the surveyed properties, but mainly in eastern NSW (88\%; 8/9) and central-western QLD (80\%, 4/5). Scrub soils could be found in western NSW, south-eastern and far north QLD. Yellow, red or black loam and sandy soils were most commonly reported in western $(55 \% ; 5 / 9)$ and eastern NSW $(22 \% ; 2 / 9)$ (Table 8).

In the high rainfall regions, the most common nutrient deficiencies reported were iodine $(50 \% ; 7 / 14)$, calcium and/or magnesium $(50 \% ; 7 / 14)$, selenium $(43 \% ; 6 / 14)$, phosphorus $(23 \% ; 4 / 17)$ and copper $(23 \% ; 4 / 17)$. In the pastoral regions, the common nutrient deficiencies were protein/nitrogen and energy, both reported by $29 \%$ (5/17) of producers, followed by phosphorus $(18 \% ; 3 / 17)$. Overall, $26 \%(8 / 31)$ of producers did not report any nutrient deficiencies because they considered that soils on their properties did not have a nutrient deficiency or they did not have sufficient information to comment.

\section{Pasture and weeds}

In all regions, the most reported browse species were Wattles (other than Mulga and Gidgee) at 42\% (13/31), followed by 35\% (11/31) of Box/Gum trees. Mulga was only reported by $23 \%$ (7/31) of producers from pastoral regions (Table 9$)$. In some cases, the presence of three or more browse species was reported on the same property. Belah (23\%; 4/17), Black oak $(12 \% ; 2 / 17)$ and Rosewood $(12 \% ; 2 / 17)$ were only recorded in the pastoral region of western NSW. Black berry $(14 \% ; 2 / 14)$, Chicory $(14 \% ; 2 / 14)$ and Pine trees $(7 \% ; 1 / 14)$ were only reported in the high rainfall region of eastern NSW (Table 9).

Spear grass (Stipa variabilis) was the most important pasture community in both western and eastern NSW and it was reported by 32\% (10/31) of surveyed producers (Table 9). Mitchell (47\%; 8/17), Buffel (35\%; 6/17) and Flinders grass (35\%; 6/17) were the most commonly reported by producers in the pastoral regions. The presence of Phalaris (43\%; 6/14), Kikuyu (43\%; 6/14), annual Ryegrass $(36 \% ; 5 / 14)$ and Rhodes 
grass $(29 \%$; 4/14) was only reported in the high rainfall regions of eastern NSW and south-eastern QLD (Table 9). When producers were asked if there were any weed species occurring on their property, $81 \%$ (25/31) responded positively. Thistles (Carduus sp.) were the most common weeds reported by producers from eastern NSW $(78 \% ; 7 / 9)$, south-western QLD (67\%; 2/3) and western NSW (11\%; 1/9). Gidgee/bore (A. cambagei and A. tephrina) and other Acacia species were the second most noted weed species reported by $26 \%(8 / 31)$ of the surveyed producers. Patterson curse (E. plantageneum) and Black berry (Rubus fruiticosus) were reported, respectively, by 78\% (7/9) and 44\% (4/9) of producers from eastern NSW.

Overall, 19\% (6/31) of producers reported that toxic plants were reducing the performance of their herds. Copper burr (Bassia convexula) was reported by 33\% (3/9) of producers from western NSW and by $11 \%$ (1/9) of producers from eastern NSW. Pimelea (Pimelea spp.) was reported by 67\% (2/3) of producers from south-western QLD and by $20 \%$ (1/5) of producers from central-western QLD. Turpentine (Eremophilia sp.) was reported by $22 \%$ (2/9) of producers from western NSW. Bracken Fern (Pteridium aquilinum) and Rock Fern (Cheilanthes sieberi) were reported equally by $22 \%$ (2/9) of producers from eastern NSW. Producers reported controlling toxic plants by using physical removal, herbicides and/or densely stocking the infested area with goats.

\section{Use of fencing}

Ninety-seven percent (30/31) of producers in all regions carried out some fencing activity over the last 5 years (Table 10). From this total, the most frequent reasons for fencing activities were associated with installing new watering points (47\%; 14/30), establishing goat management paddocks $(87 \% ; 26 / 30)$ and to create a new paddock $(73 \%$; 22/30). In south-eastern QLD, 100\% (4/4) of producers reported dog control as the main reason for building new fences (Table 10). In all regions, 81\% (25/31) of producers reported that they were planning fencing during the next 5 years (2013 to 2018), although this could potentially add to capital costs associated with better goat management and production. The two most important reasons for fencing in the future were to replace old fences $(55 \% ; 17 / 31)$ and to create new holding paddocks $(45 \% ; 14 / 31)$. The most common types of fences were hinge joint $(84 \% ; 26 / 31)$ and plain wire $(52 \% ; 16 / 31)$. Producers mentioned that the hinge joint fence was normally associated with a plain wire on the top. Producers also reported that they needed 11 lines of plain wire to hold goats 
in a paddock, and they mentioned that if the rectangular area in the hinge joint fence was too small, goats could be caught and may die as a result. 
Table 8. Land and pasture condition and major soil types in New South Wales and Queensland

\begin{tabular}{|c|c|c|c|c|c|c|c|c|c|}
\hline & \multicolumn{3}{|c|}{ Pastoral regions } & \multirow[b]{2}{*}{$\begin{array}{c}\text { Subtotal } \\
\mathrm{n}\end{array}$} & \multicolumn{3}{|c|}{ High rainfall regions } & \multirow[b]{2}{*}{$\begin{array}{c}\text { Subtotal } \\
\mathrm{n}\end{array}$} & \multirow[b]{2}{*}{$\begin{array}{c}\text { Overall } \\
\mathrm{n}(\%)\end{array}$} \\
\hline & $\begin{array}{l}\text { West } \\
\text { NSW }\end{array}$ & $\begin{array}{c}\text { S.West } \\
\text { QLD }\end{array}$ & $\begin{array}{l}\text { C.West } \\
\text { QLD }\end{array}$ & & $\begin{array}{c}\text { East } \\
\text { NSW }\end{array}$ & $\begin{array}{l}\text { S.East } \\
\text { QLD }\end{array}$ & $\begin{array}{c}\text { North } \\
\text { QLD }\end{array}$ & & \\
\hline Number of properties & 9 & 3 & 5 & 17 & 9 & 4 & 1 & 14 & $31(100)$ \\
\hline \multicolumn{10}{|c|}{ Land condition } \\
\hline Very good & 1 & 1 & 2 & 4 & 1 & 1 & 0 & 2 & $6(19)$ \\
\hline Good & 2 & 2 & 3 & 7 & 2 & 2 & 0 & 4 & $11(35)$ \\
\hline Average & 4 & 0 & 0 & 4 & 6 & 0 & 1 & 7 & $11(35)$ \\
\hline Poor & 2 & 0 & 0 & 2 & 0 & 1 & 0 & 1 & $3(10)$ \\
\hline \multicolumn{10}{|c|}{ Land Erosion } \\
\hline Yes & 4 & 2 & 2 & 8 & 3 & 1 & 1 & 5 & $13(42)$ \\
\hline No & 5 & 1 & 3 & 9 & 6 & 3 & 0 & 9 & $18(58)$ \\
\hline \multicolumn{10}{|c|}{ Pasture condition } \\
\hline Very good & 0 & 0 & 2 & 2 & 1 & 1 & 0 & 2 & $4(13)$ \\
\hline Good & 3 & 2 & 2 & 7 & 0 & 1 & 0 & 1 & $8(26)$ \\
\hline Average & 4 & 1 & 1 & 6 & 4 & 2 & 1 & 7 & $13(42)$ \\
\hline Poor & 2 & 0 & 0 & 2 & 4 & 0 & 0 & 4 & $6(19)$ \\
\hline \multicolumn{10}{|c|}{ Pasture spelling } \\
\hline Yes & 7 & 3 & 4 & 14 & 9 & 4 & 1 & 14 & $28(90)$ \\
\hline No & 2 & 0 & 1 & 3 & 0 & 0 & 0 & 0 & $3(10)$ \\
\hline \multicolumn{10}{|c|}{ Major Soil types } \\
\hline Clay soils (Vertosols) & 4 & 3 & 4 & 11 & 8 & 1 & 1 & 10 & $21(68)$ \\
\hline Yellow/ Red/ Black loam & 5 & 3 & 1 & 9 & 2 & 1 & 1 & 4 & $13(42)$ \\
\hline Sandy and Alluvial soils & 4 & 1 & 1 & 6 & 4 & 1 & 0 & 5 & $11(35)$ \\
\hline Scrub soils & 2 & 0 & 0 & 2 & 0 & 1 & 1 & 2 & $4(13)$ \\
\hline Rocky/skeletal soils & 0 & 0 & 0 & 0 & 3 & 0 & 1 & 4 & $3(10)$ \\
\hline
\end{tabular}


Table 9. Major browse and natural pasture species reported in the pastoral and high rainfall regions of New South Wales and Queensland

\begin{tabular}{|c|c|c|c|c|c|c|c|}
\hline & $\begin{array}{l}\text { Pastoral } \\
\text { Regions }\end{array}$ & $\begin{array}{l}\text { High } \\
\text { rainfall } \\
\text { regions }\end{array}$ & $\begin{array}{l}\text { Overall } \\
\text { Browse } \\
\text { species }\end{array}$ & & $\begin{array}{l}\text { Pastoral } \\
\text { Regions }\end{array}$ & $\begin{array}{l}\text { High } \\
\text { rainfall } \\
\text { regions }\end{array}$ & $\begin{array}{l}\text { Overall } \\
\text { Pasture } \\
\text { species }\end{array}$ \\
\hline Major browse species & $\mathrm{n}$ & $\mathrm{n}$ & $\mathrm{n}\left(\%^{1}\right)$ & Major natural pasture species & $\mathrm{n}$ & $\mathrm{n}$ & $\mathrm{n}\left(\%^{1}\right)$ \\
\hline Wattle (Acacia spp.) & 4 & 9 & $13(42)$ & Spear grass (Stipa variabilis) & 6 & 4 & $10(32)$ \\
\hline Box/Gum trees (Eucalyptus spp.) & 5 & 6 & $11(35)$ & Mitchell (Astrebla sp.) & 8 & 0 & $8(26)$ \\
\hline Mulga (Acacia aneura) & 7 & 0 & $7(23)$ & Buffel grass (Cenchrus ciliaris) & 6 & 2 & $8(26)$ \\
\hline Blue bush (Chenopodium sp.) & 4 & 1 & $5(16)$ & Summer grass (Digitaria sp.) & 3 & 3 & $6(19)$ \\
\hline Gidgee (Acacia cambagei) & 4 & 1 & $5(16)$ & Flinders (Iseilema macratherum) & 6 & 0 & $6(19)$ \\
\hline Salt bush (Atriplex sp.) & 5 & 0 & $5(16)$ & Phalaris (Phalaris aquatica) & 0 & 6 & $6(19)$ \\
\hline Belah (Casuarina cristata) & 4 & 0 & $4(13)$ & Kikuyu (Pennisetum clandestinum) & 0 & 6 & $6(19)$ \\
\hline Black oak (Casurina spp.) & 2 & 0 & $2(6)$ & Ryegrass (Lolium rigidum) & 0 & 5 & $5(16)$ \\
\hline Rosewood (Heterodendrum sp.) & 2 & 0 & $2(6)$ & Wiregrass (Aristida latifolia) & 4 & 1 & $5(16)$ \\
\hline Turkey bush (Eremophila spp.) & 2 & 0 & $2(6)$ & Barley grass (Hordeum leporinum) & 0 & 4 & $4(13)$ \\
\hline Prickly acacia (Acacia nilotica) & 2 & 0 & $2(6)$ & Cocksfoot (Dactylis glomerata) & 0 & 4 & $4(13)$ \\
\hline Burr medic (Medicago sp.) & 1 & 1 & $2(6)$ & Rhodes grass (Chloris gayana) & 0 & 4 & $4(13)$ \\
\hline Brigalow (A. harpophyla) & 1 & 1 & $2(6)$ & Spear grass (Heteropogon contortus) & 2 & 1 & $3(10)$ \\
\hline Black berry (Rubus fruiticosus) & 0 & 2 & $2(6)$ & Couch grass (Cynodon sp.) & 0 & 3 & $3(10)$ \\
\hline Chicory (Cichorium sp.) & 0 & 2 & $2(6)$ & Bluegrass (Dichanthium sericium) & 0 & 3 & $3(10)$ \\
\hline Pines (Pinus sp.) & 0 & 1 & $1(3)$ & Copper Burr (Bassia spp.) & 3 & 0 & $3(10)$ \\
\hline Geebung (Persoonia acerosa) & 0 & 1 & $1(3)$ & Clovers (Trifolium sp.) & 0 & 2 & $2(6)$ \\
\hline
\end{tabular}

${ }^{1}$ From the total number of properties $(\mathrm{n}=31)$. 
Table 10. Characteristics of fencing undertaken on surveyed properties and its reported purpose

\begin{tabular}{|c|c|c|c|c|c|c|c|c|c|}
\hline \multirow[b]{2}{*}{ Characteristics } & \multicolumn{3}{|c|}{ Pastoral regions } & \multirow[b]{2}{*}{$\begin{array}{c}\text { Subtotal } \\
\mathrm{n}\end{array}$} & \multicolumn{3}{|c|}{ High rainfall regions } & \multirow[b]{2}{*}{$\begin{array}{c}\text { Subtotal } \\
\mathrm{n}\end{array}$} & \multirow[b]{2}{*}{$\begin{array}{c}\text { Overall } \\
\mathrm{n}(\%)\end{array}$} \\
\hline & $\begin{array}{l}\text { West } \\
\text { NSW }\end{array}$ & $\begin{array}{c}\text { S.West } \\
\text { QLD }\end{array}$ & $\begin{array}{l}\text { C.West } \\
\text { QLD }\end{array}$ & & $\begin{array}{c}\text { East } \\
\text { NSW }\end{array}$ & $\begin{array}{l}\text { S.East } \\
\text { QLD }\end{array}$ & $\begin{array}{l}\text { North } \\
\text { QLD }\end{array}$ & & \\
\hline Number of properties & 9 & 3 & 5 & 17 & 9 & 4 & 1 & 14 & $31(100)$ \\
\hline \multicolumn{10}{|c|}{ Fencing over the last 5 years } \\
\hline No & 0 & 0 & 1 & 1 & 0 & 0 & 0 & 0 & $1(3)$ \\
\hline Yes, associated with waters & 6 & 1 & 3 & 10 & 2 & 1 & 1 & 4 & $14(45)$ \\
\hline Yes, not associated with waters & 3 & 2 & 1 & 6 & 7 & 3 & 0 & 10 & $16(52)$ \\
\hline \multicolumn{10}{|c|}{ Reasons for the use of fence } \\
\hline Goat management paddock & 8 & 2 & 3 & 13 & 9 & 3 & 1 & 13 & $26(84)$ \\
\hline Create new paddock & 6 & 3 & 2 & 11 & 7 & 3 & 1 & 11 & $22(71)$ \\
\hline Build a new lane & 0 & 1 & 3 & 4 & 4 & 2 & 0 & 6 & $10(32)$ \\
\hline Fence for dog control & 0 & 0 & 1 & 1 & 0 & 4 & 1 & 5 & $6(19)$ \\
\hline Fence out a problem area & 1 & 0 & 1 & 2 & 2 & 2 & 0 & 4 & $6(19)$ \\
\hline \multicolumn{10}{|c|}{ Plan fencing for the future } \\
\hline Yes & 7 & 3 & 4 & 14 & 7 & 3 & 1 & 11 & $25(81)$ \\
\hline No & 2 & 0 & 1 & 3 & 2 & 1 & 0 & 3 & $6(19)$ \\
\hline \multicolumn{10}{|c|}{ Reasons for fencing in future } \\
\hline Replace old fence & 5 & 1 & 4 & 10 & 5 & 2 & 0 & 7 & $17(55)$ \\
\hline Create new holding paddock & 4 & 1 & 1 & 6 & 7 & 1 & 0 & 8 & $14(45)$ \\
\hline Build lane ways & 0 & 2 & 2 & 4 & 3 & 1 & 1 & 5 & $9(29)$ \\
\hline Create a new main paddock & 0 & 1 & 0 & 1 & 5 & 0 & 1 & 6 & $7(23)$ \\
\hline Fence out country types & 1 & 0 & 0 & 1 & 2 & 0 & 0 & 2 & $3(10)$ \\
\hline Fence out a problem areas & 1 & 0 & 0 & 1 & 1 & 0 & 0 & 1 & $2(6)$ \\
\hline \multicolumn{10}{|c|}{ Kind of fence used } \\
\hline Hinge joint & 6 & 3 & 3 & 12 & 9 & 4 & 1 & 14 & $26(84)$ \\
\hline Plain wire & 9 & 1 & 3 & 13 & 2 & 0 & 1 & 3 & $16(52)$ \\
\hline Electric fence & 0 & 2 & 2 & 4 & 5 & 3 & 0 & 8 & $12(39)$ \\
\hline Barbed wire & 2 & 1 & 4 & 7 & 0 & 1 & 0 & 1 & $8(26)$ \\
\hline
\end{tabular}




\section{Use of pasture development strategies}

Seventy-seven percent (24/31) of producers interviewed had undertaken some pasture development activity in the past five years and 58\% (18/31) of producers had undertaken these activities in 2012 or 2013 . Only 23\% (7/31) of surveyed producers did not engage in pasture development in the previous five years to 2012. The types of pasture development strategies employed by $78 \%$ (7/9) of producers surveyed from eastern NSW were the use of fertilizer, sowing improved grasses and sowing improved legumes. 'Crash grazing' with goats was the most common pasture development strategy mentioned by $19 \%(6 / 31)$ of producers. This involved putting goats in a paddock at a high stocking rate to promote the reduction of undesirable shrubs or weedy species. The pasture strategy of broadcasting seeds into grassland was exclusively mentioned by producers from eastern NSW $(22 \% ; 2 / 9)$ and south-eastern QLD (75\%; 3/4). Pulling trees/vegetation and sowing improved grasses or sowing native pasture was widely used in south-western QLD $(100 \% ; 3 / 3)$ and central-western QLD $(60 \% ; 3 / 5)$. The pasture development strategies of adding limestone and/or diatomaceous earth (33\%; 3/9), blade ploughing of woody weeds (22\%; 2/9) and direct-drill disc seeding (22\%; 2/9) were reported exclusively by the producers from western and eastern NSW.

Overall, $48 \%(15 / 31)$ of producers used fire on their properties. The reasons for using fire included reducing fire risk $(23 \% ; 7 / 31)$, grazing management (i.e. increasing the number of goats in certain areas, $23 \% ; 7 / 31)$, controlling woody weeds $(19 \% ; 6 / 31)$ and encouraging growth of pasture species $(16 \% ; 5 / 31)$.

Pasture improvement with legumes was reported by 29\% (9/31) of producers and the pasture improvement with grasses was reported by $32 \%(10 / 31)$ of producers. The two most important legumes reported by producers from eastern NSW were lucerne (Medicago sativa) by 67\% (6/9) and clovers (Trifolium sp.) by 33\% (3/9). Thirty-three percent (3/9) of producers from eastern NSW reported using improved grasses such as phalaris (Phalaris aquatic), cocksfoot (Dactylis glomerata) and annual ryegrass (Lolium rigidum). Sixteen percent (5/31) of surveyed producers reported using forage crops such as oats (Avena sativa). Very limited pasture development/sowing of improved grasses or legumes were reported from central-western QLD, south-eastern QLD and northern QLD. 


\section{Discussion}

This study represents the first comprehensive survey of farming practices related to the management of meat goat producing enterprises within New South Wales and Queensland. Goats were the most important livestock enterprise on 55\% of surveyed properties, but goats were farmed in conjunction with cattle and or sheep. Goats, when grazed with sheep and cattle, have been shown to have a beneficial influence on pasture management (McGregor 2010a; Rosa García et al. 2012). A positive association existed between the number of goats in the herds and property size (Fig. 2a) and a negative association between stocking rate and property size (Fig. 2b). The explanation for these associations is that dry matter production is limited by rainfall and therefore lower rainfall regions are associated with large property sizes (Fig. 2c) that are required to maintain a sustainable living area for producers.

The survey revealed similarities of issues and factors between properties located in the pastoral regions, and some other similarities between properties located in the high rainfall regions. In the following discussion, the authors have attempted to deal with this complexity by discussing the results under sub-headings to build a better understanding of the goat industry.

\section{Goat meat markets}

The export carcass market was the most important sector in $100 \%$ of the properties in pastoral regions (Table 6). This represented $97 \%$ of the goat herd in this survey. These results are in agreement with the Australian Bureau of Statistics which reported that the export carcass market represents around $96.5 \%$ of the goat industry, whereas live export only represents 3.5\% (McRae and Thomas 2014). In this survey, the domestic market was used by $81 \%$ of producers. This is probably because a large number of properties were selling goats to store operations, dealer depots, other properties and, to a lesser extent, selling goat meat to restaurants. However, the amount of goat meat sold to restaurants in Australia is very low. Schuster (2006) reported that only about 5\% of goats slaughtered enter the domestic market and this goat meat is sold through ethnic butchers in Melbourne and Sydney.

A constraint identified by $53 \%$ of goat producers in the pastoral regions that limited the continuity of supply was the long distances from their property to an abattoir (>600 km; Table 6) and as a consequence the greater cost of freight. Distances to abattoirs 
longer than $300 \mathrm{~km}$ require an 8 deck lot of animals (approximately 700-800 goats) to reduce the freight cost per animal. Furthermore, management decisions in the pastoral regions take into account the price received per kilogram on farm. If the price offered is not considered adequate to make a profit then no harvest takes place, although goats are available to enter the supply chain. According to Brice et al. (2012), one of the greatest challenges facing the Australian goat meat industry is the inconsistent supply of product throughout the year. In an attempt to fulfil market demand, high prices will be offered for product supplied outside the normal production cycle (McRae and Thomas 2014), although other authors have recommended that producers prepare their goats to meet market specifications for age, liveweight or carcass weight and condition score in order to maximise the price received to producers (McGregor 2012). Historically, prices for rangeland and Boer goat cross breeds have been quite volatile. Goat meat prices are subject to fluctuations in response to supply and demand, exchange rates and affordability to consumers (Clarke and Ronning 2013).

\section{Land, pasture and stocking rate}

The reported stocking rate in this survey varied from 0.3 goats/ha to 9.3 goats/ha. This is similar to what has been previously reported by Ferrier and McGregor (2002) who found a stocking rate varying from 0.2 goats/ha to 4.2 goats/ha in Victoria. These authors suggested that producers were underestimating their stocking rates, especially when mixed with other grazing species. In this survey, producers from western NSW and central-western QLD also tended to underestimate their stocking rates, highlighted by inconsistencies between the reported and calculated stocking rates (Table 2). Underestimation of stocking rates can be a problem, as high stocking rates can cause overgrazing, degradation of rangeland vegetation, reduced groundcover, and increased soil erosion (Bayne et al. 2004; Brice et al. 2012; Hacker and Alemseged 2014). High stocking rates of 7.5 goats/ha has been reported as possible in a high rainfall region of Victoria without negatively affecting the botanical composition or ground cover (McGregor 2010a). However, careful management of the goat herd was required to achieve this stocking rate, inclusive of supplementary feeding and containment areas during periods of drought.

Fifty-five percent (17/31) of producers reported very good or good land conditions, but only 39\% (12/31) reported very good or good pasture conditions (Table 8). These results imply that the pasture is not totally expressing the quality of the land on 
which it is grown or that producers are measuring incorrectly their land and pasture conditions. This could be due to pasture management or other limiting factors, such as rainfall.

Producers in the pastoral regions reported changes in stocking rate to match seasonal conditions (Table 3). It is unknown if the changes in stocking rates occur naturally due to fluctuations in seasonal conditions or if it is managed by producers. For instance, during a 'poor season' kidding rates can be lower and mortality rates can be higher and as a consequence the number of goats on a property can decline. In contrast, in a 'good season' reproductive rates and survival rates may increase and stocking rates would naturally increase. Producers in the high rainfall regions, however, reported an unwillingness to modify stocking rate according to seasonal conditions because of limited property area and pasture shortages. Furthermore, the highest stocking rates ( $>3$ goats/ha) on these properties can be explained by the higher rainfall and by supplementary feeding of animals (Nogueira et al., 2014).

In the pastoral regions of western NSW, the stocking rates of 0.5 goats/ha within the Mulga may be optimal for achieving a balance between weed control and regrowth of herbage, although a stocking rate of 2 goats/ha, resulted in hopbushes being rapidly killed and mulga being defoliated (Downing 1986). It is recommended that in dry seasons, where palatable plant species are in short supply, a stocking rate below that considered to be appropriate for the area should be applied and plant species monitored to avoid eradicating the species and increasing soil erosion by removal of pasture litter (Harrington 1986). Setting and adjusting the stocking rate is a critical management practice that is required for maintaining sustainability (McGregor 2010a; Hacker and Alemseged 2014).

\section{Browse and pasture species}

The meat goat industry in the pastoral regions is largely based on the utilization of natural pastures and browse species. A similar observation was made by Bortolussi et al. (2005c) with respect to the cattle industry. This survey shows that goats in Australia are adapted to eat a variety of plants including wattle, gum trees, mulga and prickly acacias (Table 9). According to Squires (1980), shrubs, specifically mulga (Acacia aneura), hopbush (Dodonea viscose) and broom brush (Apophyllum anomalum) contributed more than $50 \%$ to the diet of goats in north-western NSW. In the present study, mulga was reported by $23 \%$ of producers (Table 9), but no producers in any region mentioned hopbush or broom brush. Producers reported that goats browsed belah and 
rosewood species, and goats also ate spear grass and copper burr. Similar results were found by Wilson et al. (1975) who reported that goats ate a large amount of rosewood and belah, in comparison to sheep, but sheep preferred to eat mainly spear grass and copper burr.

The results of the present survey suggest that some of the woody weeds that are not readily utilised by cattle and sheep can be utilized for goat production (Simmonds $e t$ al. 2000). This is because goats are more selective compared to sheep and goats have the flexibility of browsing and grazing different plants (Silanikove 2000; McGregor 2005; McGregor 2010a).

The most commonly reported pasture species present on surveyed properties were spear grass, mitchell, buffel and flinders grass (Table 9), and these pasture species were normally found in dry environments. Therefore, there is opportunity to capitalise on the ability of goats to better utilise pasture in summer, suggesting that goats have an advantage over sheep in either selecting and/or digesting low quality pasture. This advantage can result in increased gains in goats compared to sheep during seasonally dry periods and reductions in supplementary feed required during period of drought (McGregor 2010b).

\section{Weeds and toxic plants}

To the producers in the pastoral regions, the most important benefit of having goats on their properties is the control of weeds and undesirable browse species. This supports the argument that goats act as biological control agents and have an advantage over other control methods such as mechanical cutting and herbicide application, which are expensive and have a negative impact on the environment (Magadlela et al. 1995; Simmonds et al. 2000).

While it is thought that goats are able to develop a tolerance to some toxic plants (Downing 1986), 19\% of producers reported that toxic plants were reducing the performance of their herd. For instance, turpentine was mentioned as a toxic plant by $22 \%$ of producers from western NSW, however, in previous studies, turpentine was reported to be unpalatable or rarely eaten by goats (Wilson et al. 1975; Squires 1980), which may explain the drop in performance seen by producers.

\section{Pasture development strategies}

The lowest incidence of pasture development strategies was reported by producers in western NSW and central-western QLD, which reflects a majority of properties with 
rainfall below $500 \mathrm{~mm}$ and the overall presence of heavy clay soils (68\%). These regions rely almost entirely on native grass, such as mitchell, flinders and spear grasses, which could reduce animal productivity. Productivity of goats in the semi-arid regions could potentially be raised by improving the feed base with grasses and legumes where appropriate. In subtropical semi-arid regions, for example, where native or woody weeds (gidgee) have been cleared, buffel grass with the addition of an adapted legume such as Desmanthus spp. may enhance pasture quantity and quality, thereby increasing goat productivity and the sustainability of the enterprise (Gardiner et al. 2013). Moreover, Desmanthus spp. is one of few legumes species adapted to grazing in that particular semiarid clay soil environment.

\section{Conclusions}

This study provides an overview of meat goat producing enterprises in New South Wales and Queensland, Australia. Some of the important findings of the survey are that $48 \%$ producers rely on opportunistic harvesting. Rangeland goats in pastoral regions are an important source of income. Stocking rate varied considerably within pastoral regions and high rainfall regions, and was found to be negatively associated with property size and positively associated with rainfall. The results have confirmed the importance of the international market as a source of income and the utilisation of goats to control weeds on many properties. Many producers are located over $600 \mathrm{~km}$ from a processing plant and the high cost of freight can limit the continuity of goat supply to the market. The reasons for use of fencing appeared to be an important issue for goat farmers, and this could potentially add to capital costs associated with better goat management and production. Improved pasture management, strategic management of stocking rates and nutrition to meet market specifications and regional location of processing plants within $600 \mathrm{~km}$ of major areas of production could improve the utilisation and production of rangeland goats in New South Wales and Queensland.

\section{Acknowledgments}

The authors gratefully acknowledge the support of James Cook University, Empresa Brasileira de Pesquisa Agropecuária (EMBRAPA) and Meat and Livestock Australia (MLA) for the conduct of this study. We thank the landholders who kindly received us on their properties and provided information and support for this study. The authors are also grateful for the useful comments and suggestions from the reviewers. 


\section{References}

Bayne, P, Harden, R, Davies, I (2004) Feral goats (Capra hircus L.) in the Macleay River gorge system, north-eastern New South Wales, Australia. I. Impacts on soil erosion. Wildlife Research 31, 519-525.

Bortolussi, G, McEvoy, TG, Hodgkinson, J, Coffey, S, Holmes, CR (2005a) The 199697 CSIRO Northern Australian beef industry survey: methods and data classification. Australian Journal of Experimental Agriculture 60p.

Bortolussi, G, McIvor, JG, Hodgkinson, JJ, Coffey, SG, Holmes, CR (2005b) The northern Australian beef industry, a snapshot. 1. Regional enterprise activity and structure. Australian Journal of Experimental Agriculture 45, 1057-1073.

Bortolussi, G, McIvor, JG, Hodgkinson, JJ, Coffey, SG, Holmes, CR (2005c) The northern Australian beef industry, a snapshot. 4. Condition and management of natural resources. Australian Journal of Experimental Agriculture 45, 1109-1120.

Boyazoglu, J, Hatziminaoglou, I, Morand-Fehr, P (2005) The role of the goat in society: Past, present and perspectives for the future. Small Ruminant Research 60, 13-23.

Brice, B, Day, P, Burgi, A (2012) Australian goat industry RD\&E strategy. Meat \& Livestock Australia Limited, Sydney, Australia. 1, 1-58.

Clarke, M, Ronning, D (2013) 'Goatmeat industry RD\&E strategy - 2012: Benefit cost analysis.' (Meat and Livestock Australia (MLA): Sydney)

Downing, B (1986) Goat and Sheep Grazing in Shrub-Infested Semi-arid Woodlands of New South Wales. The Rangeland Journal 8, 140-150.

Dubeuf, JP, Morand-Fehr, P, Rubino, R (2004) Situation, changes and future of goat industry around the world. Small Ruminant Research 51, 165-173.

FAO (2013) Food and Agriculture Organization. Official statistics of United Nation [Online]. Available at http://faostat.fao.org/site/339/default.aspx (verified May 2013).

Ferrier, GR, McGregor, BA (2002) Benchmarks of Victorian commercial goat meat enterprises. Proceedings of the Australian Society of Animal Production 24, 6568.

Gardiner, CP, Kempe, N, Hannah, I, McDonald, J (2013) PROGARDES: a legume for tropical/subtropical semi-arid clay soils. Tropical Grasslands - Forrajes Tropicales. Proceedings of the 22nd International Grasslands Congress. 1, 7880.

Hacker, RB, Alemseged, Y (2014) Incorporating farmed goats into sustainable rangeland grazing systems in southern Australia: a review. The Rangeland Journal 36, 2533.

Harrington, G (1986) Herbivore diet in a semi-arid Eucalyptus populnea woodland. 2. Feral goats. Australian Journal of Experimental Agriculture 26, 423-429.

IBRA (2014) Interim Biogeographic Regionalisation for Australia [Online]. Available at http://www.environment.gov.au/topics/land/national-reserve-system/sciencemaps-and-data/australias-bioregions-ibra (verified August 2014).

Khairo, SA, Hacker, RB, Atkinson, TL, Turnbull, GL (2013) Alternative strategies for management of feral goats: implications for natural resource management policies in New South Wales rangelands. The Rangeland Journal 35, 201-210.

Magadlela, AM, Dabaan, ME, Bryan, WB, Prigge, EC, Skousen, JG, D'Souza, GE, Arbogast, BL, Flores, G (1995) Brush Clearing on Hill Land Pasture with Sheep and Goats. Journal of Agronomy and Crop Science 174, 1-8. 
McGregor, BA (2005) Nutrition and Management of Goats in Drought. Rural Industries Research and Development Corporation 05/188, 1-90.

McGregor, BA (2010a) Influence of stocking rate and mixed grazing of Angora goats and Merino sheep on animal and pasture production in southern Australia. 1. Botanical composition, sward characteristics and availability of components of annual temperate pastures. Animal Production Science 50, 138-148.

McGregor, BA (2010b) Influence of stocking rate and mixed grazing of Angora goats and Merino sheep on animal and pasture production in southern Australia. 2. Liveweight, body condition score, carcass yield and mortality. Animal Production Science 50, 149-157.

McGregor, BA (2012) The role of objective and subjective evaluation in the production and marketing of goats for meat. Ch.8. In 'Goat Meat Production and Quality.' (Eds O Mahgoub, IT Kadim, EC Webb.) pp. 209-230. (CABI: Wallingford)

McRae, T, Thomas, B (2014) Goat industry summary 2014. Meat and Livestock Australia Ltd. Available at http://www.mla.com.au/Prices-and-markets/Market-news/Goatindustry-summary-2014 (verified April 2014). 1, 17.

MLA (2013) Meat and Livestock Australia. Going into Goats: A practical guide to producing goats in the rangelands [Online]. Available at http://www.rangelandgoats.com.au/home (verified June 2013). 147.

Parkes, J, Henzell, R, Pickles, G (1996) 'Managing vertebrate pests: feral goats.' (Australian Government Publishing Service: Canberra)

Restall, BJ, Mitchell, TD, Holst, PJ, Pym, RA, Nicholls, PJ, Norton, BW, Davies, L (1982) Australian feral goat: basis for a new industry? . Proceedings of the Australian Society of Animal Production 14, 130-145.

Rosa García, R, Celaya, R, García, U, Osoro, K (2012) Goat grazing, its interactions with other herbivores and biodiversity conservation issues. Small Ruminant Research 107, 49-64.

Schuster, P (2006) Supply profile of the Australian goat meat industry. Meat and Livestock Australia (MLA)

Silanikove, N (2000) The physiological basis of adaptation in goats to harsh environments. Small Ruminant Research 35, 181-193.

Simmonds, H, Holst, PJ, Bourke, C (2000) 'The Palatability and Potential Toxicity of Australian Weeds to Goats.' (Rural Industries Research and Development Corporation:

Squires, V (1980) Chemical and botanical composition of the diets of oesophageally fistulated sheep, cattle and goats in a semi-arid Eucalyptus populnea woodland community. The Rangeland Journal 2, 94-103.

Wilson, A, Leigh, J, Hindley, N, Mulham, W (1975) Comparison of the diets of goats and sheep on a Casuarina cristata - Heterodendrum oleifolium woodland community in western New South Wales. Australian Journal of Experimental Agriculture 15, 45-53.

Nogueira DM, Gardiner CP, Gummow B, Cavalieri J, Fitzpatrick LA, Parker AJ (2014) A Survey of the Queensland and New South Wales Meat Goat Industry. 2. Herd management, reproductive performance and animal health. Animal Production Science (Paper 2 under review). 